\title{
Pengembangan Mobile Learning dengan Pendekatan Saintifik untuk Meningkatkan Kemandirian dan Hasil Belajar IPS di Kelas IV SD
}

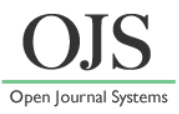

\author{
Septi Sakiyah*, Mustaji, M. Turhan Yani \\ Fakultas Pascasarjana Universitas Negeri Surabaya \\ Email: ssakiyah.19080@mhs.unesa.ac.id \\ DOI: https://doi.org/10.33369/pendipa.6.1.193-200
}

\begin{abstract}
[Development of m-learning with a Scientific Approach to Improve Independence and Social Studies Learning Outcomes in Grade IV Elementary School] The goal of this study is to develop m-learning with a Scientific Approach to Improve Independence and Social Studies Learning Outcomes for Grade IV Elementary School. This study uses the DDD-E (Decide, Design, Develeop, and Evaluate) model by Ivers \& Barron. The subjects of the research were fourth grade students of SDN Pucang 1 Sidoarjo which consisted of 35 students. Data collection techniques were in the form of documentation, validation, observation, questionnaires, and tests. The results of the research include: (1) M-learning based on its appearance gets an average score of 3.9, while based on the material it gets an average score of 3.37; (2) The results of the implementation of lesson plans and student's responses to the use of m-learning were $97.72 \%$ with positive response criteria; (3) The analysis results of the independence of students show the results of $t$-statistics $11,689>t$-table $=2,042$, therefore a significant difference between $X_{1}$ and $X_{2} ;(4)$ Student learning outcomes show an increase. This study develops the concept of making contextual $m$ learning and it's prioritizes the role of students to be independent and active during learning activities.
\end{abstract}

Keywords: M-learning, scientific, independent, and learning outcomes.

\begin{abstract}
ABSTRAK
Penelitian ini bertujuan untuk mengembangkan m-learning dengan Pendekatan Saintifik untuk Meningkatkan Kemandirian dan Hasil Belajar IPS di Kelas IV SD. Penelitian ini menggunakan model DDD-E (Decide, Design, Develop, and Evaluate) oleh Ivers \& Barron. Subyek penelitian yaitu siswa kelas IV SDN Pucang 1 Sidoarjo yang terdiri dari 35 siswa. Teknik pengumpulan data berupa dokumentasi, validasi, observasi, angket, dan tes. Hasil penelitian meliputi: (1) Kevalidan M-learning berdasarkan tampilannya memperoleh nilai rata-rata 3,9, sedangkan berdasarkan materinya memperoleh nilai rata-rata 3,37; (2) Kepraktisan kualitas produk berdasarkan hasil keterlaksanaan RPP dan respon siswa terhadap penggunaan m-learning sebanyak 97,72\% dengan kriteria respon positif; (3) Keeefektifan dari hasil analisis kemandirian peserta didik menunjukkan hasil t-statistik 11,689>t-tabel $=2,042$, maka terdapat perbedaan signifikan antara $X_{1}$ dan $X_{2}$; (4) Keefektifan dari hasil belajar siswa dengan menggunakan m-learning menunjukkan peningkatan yang signifikan. Penelitian ini mengembangkan konsep pembuatan $m$-learning berbasis saintifik yang disesuaikan dengan lingkungan peserta didik serta mengutamakan peran peserta didik untuk memiliki sikap kemandirian dalam kegiatan pembelajaran.
\end{abstract}

Kata Kunci: M-learning, saintifik, kemandirian, dan hasil belajar.

\section{PENDAHULUAN}

Kegiatan pembelajaran merupakan sebuah proses komunikasi. Proses komunikasi tersebut berlangsung tidak jarang mengalami hambatan, sehingga dibutuhkan perantara yang mampu menjembatani antara guru dan peserta didik yang dikenal dengan sebutan media. Media pembelajaran mempunyai peranan yang cukup penting guna membantu tercapainya tujuan pembelajaran yang telah ditetapkan. (Daryanto, 
2010) menjelaskan bahwa penggunaan media pembelajaran mampu mengatasi keterbatasan tenaga, waktu, ruang, serta mampu menstimulus gairah belajar. Pengembangan media pembelajaran digunakan untuk menyelesaikan masalah dalam kegiatan belajar, salah satu bentuk dari pengembangan media yaitu dengan pemanfaatan teknologi. Perkembangan teknologi yang semakin berkembang menawarkan banyak media alternatif yang bisa dipakai guru dalam mendampingi peserta didik belajar, salah satunya m-learning yang dapat diakses melalui smartphone.

Penggunaan m-learning diharapkan mampu menarik minat belajar dan meningkatkan rasa kemandirian peserta didik dalam kegiatan belajar. Kemandirian adalah salah satu perilaku yang membuat peserta didik untuk melakukan sesuatu atas kemauan diri sendiri untuk mengatur diri menyelesaikan persoalan dan dapat bertanggung jawab terhadap sikap yang telah diambil. (Qohar, 2011) menjelaskan agar dapat memiliki kemandirian dalam belajar, peserta didik harus mempunyai pengetahuan tentang dirinya sendiri, materi atau tugas yang akan dipelajari, strategi dalam belajar dan implementasi materi dalam kehidupan seharihari. Kemandirian belajar yang baik memungkinkan peserta didik mendapatkan hasil belajar yang baik pula karena peserta didik termotivasi untuk belajar atas keinginannya sendiri dan hal ini sesuai dengan tujuan pendekatan saintifik dalam kegiatan pembelajaran peserta didik setiap harinya.

Kemandirian bukanlah hasil yang diperoleh dari proses internalisasi antara otoritas melainkan suatu proses perkembangan sikap diri. Kemandirian peserta didik juga termasuk kemandirian dalam belajar (Asrori, 2015). Proses belajar yang sesungguhnya bukan hanya kegiatan menghafal. Peserta didik tidak hanya memperoleh pengetahuan maupun nilai yang diberikan guru tetapi juga mengelolahnya menjadi kesatuan yang bermakna. Proses pengolahan tersebut terjadi dalam diri peserta didik sehingga kemandirian tidak dapat dipisahkan dari kegiatan belajar (Melvin, 2006). Berdasarkan pendapat tersebut, dapat disimpulkan bahwa kemandirian adalah salah satu karakter yang dibentuk di sekolah sesuai dengan desain pendidikan di Indonesia yang merupakan kemampuan untuk melakukan dan memutuskan segala sesuatu sesuai dengan keadaan dirinya sendiri tanpa ada pengaruh atau bantuan dari orang lain.

Produk media berbasis m-learning dapat dimanfaatkan guru sebagai bahan belajar IPS yang lebih menarik, melibatkan peserta didik secara langsung sehingga diharapkan mampu membuat peserta didik lebih mandiri dalam kegiatan pembelajaran tanpa harus menunggu dibimbing oleh orang tua maupun guru les, karena dibuat berdasarkan perkembangan jaman dan teknologi yang dapat mengoptimalkan smartphone menjadi lebih efektif dan positif. Penggunaan pendekatan saintifik didasarkan pada penerapan kurikulum K-13 yang berlandaskan pada pendekatan ini guna mengajak peserta didik lebih mandiri dan diharapkan mampu meningkatkan hasil belajar. (Effendi dan Zhuang, 2005) mengklasifikasikan m-learning yaitu: (1) Synchronous Training, synchronous adalah waktu yang bersamaan, yang artinya peserta didik dan guru melaksanakan kegiatan pembelajaran dalam waktu yang bersamaan; (2) Asynchronous Training, asynchronous adalah waktu yang tidak bersamaan, yang artinya peserta didik dapat belajar lebih fleksibel kapan saja dan dimana saja adanya kehadiran guru. Pengembangan m-learning dengan materi kegiatan ekonomi dan hubungannya dengan berbagai bidang pekerjaan dapat terapkan dengan menggunakan smartphone maupun laptop sehingga peserta didik dapat belajar dengan mandiri atau asynchrounus training. Melalui model tersebut peserta didik didorong untuk 
mampu memahami konsep materi yang ada sesuai dengan tingkat penguasaan masingmasing.

Hasil wawancara di lapangan dengan guru kelas IV SDN Pucang 1 dapat diketahui bahwa efektivitas dan respon siswa terhadap kegiatan pembelajaran daring sangat rendah terutama pada pelajaran IPS. Pemberian materi sesuai dengan buku tema yang disajikan dalam bentuk pdf dan memanfaatkan google classroom sebagai sarana untuk share materi yang telah dipersiapkan guru ternyata mendapatkan respon yang kurang positif dari peserta didik, hal ini terbukti dari 35 peserta didik hanya 10 peserta didik yang mengumpulkan tugas tepat waktu. Penyebab peserta didik mengumpulkan terlambat sangat beragam mulai dari tidak adanya kuota internet, mengerjakan harus menunggu dibimbing orang tua, lupa tidak melihat tugas yang diberikan guru sehingga terlambat mengerjakan, bahkan ada peserta didik yang menunggu guru les untuk membantu mengerjakan tugas tersebut. Hasil wawancara tersebut menunjukkan bahwa kurangnya sikap mandiri peserta didik dalam mengerjakan tugas yang telah disampaikan oleh guru. Hasil belajar dari 35 peserta didik hanya 15 peserta didik yang mendapatkan nilai di atas KKM (nilai 78). Penyebab banyaknya peserta didik yang mendapatkan nilai di bawah KKM karena peserta didik kurang tertarik dan sudah bosan dengan model pembelajaran daring dan materi ajar yang diberikan guru hanya sebatas dari buku teks yang dilakukan oleh guru.

Karakteristik pembelajaran IPS yang menggunakan pendekatan lingkungan, memotivasi peserta didik agar kreatif, inovatif, dan aktif sesuai dengan perkembangan peserta didik, serta mampu meningkatkan keterampilan peserta didik dalam berfikir dan memperluas pengetahuan tentang budaya membuat peneliti ingin mengembangkan sebuah m-learning yang berbasis lingkungan geografis yang dikenal sebagai kawasan delta dengan hasil utama perikanan sehingga dapat mengkontruksi kemampuan kognitif siswa secara maksimal utamanya pada materi jenis-jenis pekerjaan yang ada di tempat tinggalku yaitu Kabupaten Sidoarjo. Kehadiran m-learning pada kegiatan pembelajaran diperlukan dalam rangka kepentingan bahan belajar untuk mencapai kompetensi yang ada pada kurikulum. Berdasarkan uraian di atas, maka penulis tertarik untuk melakukan penelitian pengembangan yaitu Pengembangan m-learning dengan Pendekatan Saintifik untuk Meningkatkan Kemandirian dan Hasil Belajar IPS di Kelas IV SD”.

\section{METODE PENELITIAN}

Model penelitian pengembangan ini dikenal dengan sebutan DDDE dari (Ivers and Barron 2002). Latar belakang penggunaan model DDDE yaitu cocok untuk mengembangkan sebuah produk multimedia dan mempunyai tahapan yang sistematis dimana pada setiap tahapan harus mengacu pada tahap sebelumnya yang sudah direvisi sehingga dapat menghasilkan produk yang baik pula. Model penelitian DDDE dilakukan secara berurutan dan berkesinambungan serta lebih sederhana dari model penelitian pengembangan lainnya. Tahapan pengembangan media m-learning menggunakan DDDE (Ivers and Baron, 2002) yang terdapat ppada gambar di bawah ini.

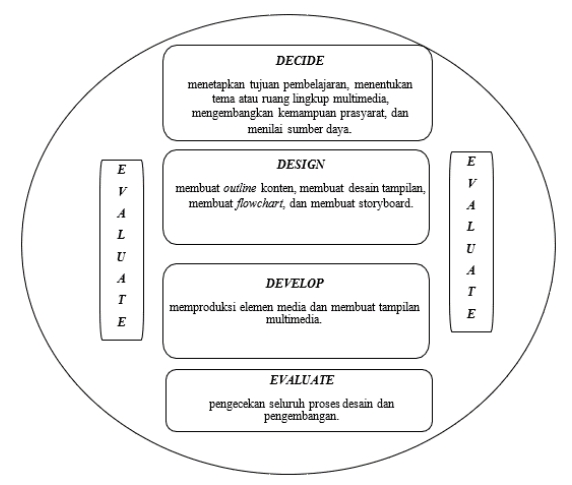

Gambar 1 Tahapan Penelitian Pengembangan Model DDDE (Ivers \& Baron 2002) 
Berdasarkan uraian model penelitian dan pengembangan di atas, penelitian pengembangan model DDDE terdapat 4 tahapan prosedur antara lain: (1) Decide, yaitu dengan menetapkan tujuan pembelajaran, menentukan tema atau ruang lingkup multimedia, mengembangkan kemampuan prasyarat, dan menilai sumber daya; (2) Design, yaitu dengan membuat outline konten, membuat desain tampilan, membuat flowchart, dan membuat storyboard; (3) Develop, yaitu dengan memproduksi elemen media dan membuat tampilan multimedia dengan memanfaatkan program m-learning ini dibuat dengan menggunakan aplikasi Adobe Animate yang memanfaatkan fitur animasi, grafik raster, embedding audio, dan skrip actionscript dari Adobe Systems; (4) Evaluate, yaitu dengan melakukan pengecekan seluruh proses desain dan pengembangan sehingga m-learning yang telah dibuat dapat digunakan secara maksimal sesuai dengan tujuan pembelajaran yang ingin di capai.

$\begin{array}{cccc}\text { Data } & \text { diperoleh } & \text { dari } & \text { proses } \\ \text { pengembangan } & \text { m-learning } & \text { dan } & \text { kualitas }\end{array}$ pengembangan m-learning menurut validator dan uji coba produk maka data hasil penelitian ini antara lain: (1) Data hasil tahap analisis dan desain berupa rumusan tujuan pembelajaran dari KI dan KD tema 8 kelas IV SD pada kurikulum 2013. Hasil observasi lapangan dan draf proposal. Hasil dari tahap analisis dan desain menjadi data untuk proses penelitian pengembangan ini; (2) Nilai dari validator ketika tahap pengembangan merupakan data yang digunakan untuk menjawab masalah kualitas dari m-learning dari segi produk berupa kelayakan materi, penyajian bahasa, dan kegrafikan; (3) Nilai dari penggunaan m-learning merupakan hasil dari analisis guru dan siswa ketika menggunakan m-learning ini dalam kegiatan pembelajaran; (4) Hasil belajar siswa dilakukan melalui uji coba terbatas dan uji coba luas yang bersumber dari tahapan penilaian hasil belajar untuk mengidentifikasikan kegiatan ekonomi dan hubungannya dengan berbagai bidang pekerjaan, serta kehidupan sosial dan budaya di lingkungan sekitar melalui m-learning yang telah dikembangkan.

Prosedur analisis data untuk kualitas $m$ learning dilihat dari produknya, meliputi editing dengan memeriksa data validasi yang sudah terkunpul dari para validator. Analisis data validasi dengan menghitung masing-masing skor rata-rata. Skala yang digunakan untuk penskoran lembar validasi ini adalah skala likert (Sugiyono, 2017). Prosedur penganalisisan data untuk kepraktisan m-learning meliputi respon siswa dan keterlaksanaan perangkat pembelajaran dengan lembar observasi catatan lapangan dan angket yang berupa google form. Angket respon peserta didik digunakan untuk mengetahui pendapat dari peserta didik mengenai penerapan m-learning yang telah dikembangkan oleh peneliti. Analisis keterlaksanaan RPP dilakukan secara deskriptif kuantitatif dengan cara menghitung hasil pengamatan, selanjutnya dicari persentase mengenai keterlaksanaan RPP dalam proses pembelajaran. Analisis hasil kemandirian peserta didik dalam penelitian pengembangan ini dilakukan dengan menghitung uji $t$ untuk mengetahui perbedaan signifikan. Angket respon pertama dilakukan sebelum siswa diberikan pelajaran dan yang kedua setelah siswa diberikan pelajaran dengan memanfaatkan m-learning. Analisis hasil belajar peserta didik dalam penelitian pengembangan ini dilakukan dengan menghitung uji t untuk mengetahui perbedaan signifikan pretest dan posttest. Tes pertama dilakukan sebelum siswa diberikan pelajaran (pretest), dan yang kedua setelah siswa diberikan pelajaran (postest).

\section{HASIL DAN PEMBAHASAN}

Hasil penelitian pengembangan media pembelajaran m-learning dengan pendekatan saintifik untuk meningkatkan kemandirian dan hasil belajar IPS di kelas IV Sekolah Dasar pada tema 8 daerah tempat tinggalku. Kualitas produk 
yang dihasilkan dilihat dari hasil validasi, kepraktisan, dan keefektifan media m-learning. Kevalidan media dan telah divalidasi oleh validasi ahli materi dan media guna mendapatkan kevalidan media pada aspek materi dan tampilan. Kepraktisan m-learning diperoleh dari hasil keterlaksanaan RPP pada aktivitas guru dan respon peserta didik terhadap penggunaan $m$ learning. Keefektifan m-learning diperoleh dari hasil analisis LKPD yang berbentuk evaluasi dalam m-learning dan hasil belajar siswa ketika pretest dan posttest dalam pembelajaran.

M-learning dipilih untuk dikembangkan sebagai media pembelajaran karena sangat sesuai dengan kondisi pembelajaran daring yang digunakan selama masa pandemi covid-19. Peserta didik mampu mengeksplorasi lingkungan sekitar khususnya di Sidoarjo untuk memahami materi tentang kegiatan ekonomi secara mandiri. Sesuai dengan teori belajar kognitif Piaget ketika impilkasi dalam kegiatan pembelajaran mengutamakan peran peserta didik untuk berinisiatif sendiri melibatkan diri secara aktif selama kegiatan pembelajaran. Kegiatan di kelas tidak ditekankan pada menyajiaan pengetahuan saja melainkan juga mendorong peserta didik untuk menemukan sendiri pengetahuan itu melalui interaksi lingkungan sedangkan menurut Bruner, bahwa manusia berperan sebagai pemroses, pemikir, dan pencipta informasi sehingga hal yang terpenting dalam belajar adalah bagaimana anak memilih, mempertahankan, dan mentransformasikan informasi yang diterima secara aktif.

Pengembangan m-learning ini juga memperhatikan teori belajar yang dikemukaan oleh Brunner, dimana beliau sangat memberikan perhatian pada masalah apa yang dilakukan peserta didik dengan informasi yang telah diperoleh untuk mencapai pemahaman dan membentuk kemampuan berfikir peserta didik. Selain itu juga berlandaskan teori belajar dari Vygotsky, gagasan terpenting dari teori ini adalah scaffolding, yang berarti peserta didik memerlukan bantuan pada tahap-tahap awal kegiatan pembelajaran yang kemudian akan mulai mengurangi bantuan tersebut seiring dengan kemampuan peserta didik untuk

https://ejournal.unib.ac.id/index.php/pendipa bertanggung jawab dan melakukan sesuatu secara mandiri.

Pembelajaran dengan multimedia akan memberi kesempatan kepada siswa untuk lebih leluasa untuk belajar mandiri. Siswa dapat mengulang atau mengatur kecepatan program untuk memahami materi pelajaran. Multimedia mampu menciptakan pembelajaran yang menarik dan tidak membosankan (Surjono, 2017). Teori belajar sibernetik mengakomodasi kebutuhan peserta didik selama pembelajaran dimasa pandemi covid-19 dimana Teori ini berkembang sejalan dengan perkembangan teknologi dan ilmu informasi. Teori ini lebih mementingkan sistem informasi dari pesan atau materi yang dipelajari. Sistem informasi yang diproses yang akan dipelajari mahasiswa. Proses pengolahan informasi dalam ingatan dimulai dari proses penyandian informasi (encoding), diikuti dengan penyimpanan informasi (storage), dan diakhiri dengan mengungkapkan kembali informasiinformasi yang telah disimpan dalam ingatan (retrieval).

Kevalidan m-learning yang dikembangkan terdiri dari dua komponen yaitu kevalidan materi dan kevalidan tampilan. Hasil validasi m-learning berdasarkan tampilannya memperoleh nilai rata-rata 3,9 dan jika interpretasikan dalam bentuk prosentase makan akan menunjukkan angka 98\% yang termasuk dalam kategori dapat digunakan tanpa revisi. Hasil validasi media berdasarkan memperoleh nilai rata-rata 3,37 dengan persentase $87,27 \%$ sehingga termasuk dalam kategori dapat digunakan tanpa revisi. Hal ini didukung oleh penelitian (Muttaqin, 2020) yang menyatakan bahwa multimedia lectora inspire telah melalui tahapan uji validasi dari aspek, aspek materi, uji kepraktisan dan mendapatkan kategori baik dan berdasarkan hasil penerapannya dari segi tes yang mendapatkan kemajuan sampai $85 \%$ dan ketuntasan belajar klasikal sebanyak $88.89 \%$ yang berarti signifikan terhadap kemampuan berpikir kritis. (Utami, dkk, 2018) juga mengemukakan hal yang sama bahwa pengembangan media pembelajaran matematika berbasis mobile learning dengan pendekatan scientific pada SMP materi PLDV yang dikembangkan teruji valid secara isi dengan hasil penilaian untuk media rata-rata sebesar $91,3 \%$, 
sedangkan penilaian validator untuk materi PLDV dengan pendekatan scientific ratarata sebesar 93,6\%. Hasil tersebut berdasarkan penilaian validator memberikan nilai baik dan dapat digunakan dengan sedikit revisi.

Kepraktisan m-learning meliputi respon peserta didik dan keterlaksanaan perangkat pembelajaran dengan lembar observasi dan angket yang diberikan pada peserta didik dalam bentuk google form. Pengamatan keterlaksanaan RPP dilakukan dengan cara menghitung skor hasil pengamatan yang dilakukan oleh dua rekan sejawat yaitu guru kelas tersebut dan guru senior. Keterlaksanaan RPP memperoleh nilai rata-rata 4 yang kemudian diinterpetasi menjadi $100 \%$ dengan kriteria terlaksana dengan baik. Hasil respon siswa selama penggunaan m-learning menunjukkan skor 3 (baik) sebanyak 8 dan skor 4 (amat baik) sebanyak 342 yang kemudian diinterpretasikan menghasilkan $97,72 \%$ dengan kriteria respon positif. (Tien dkk, 2012) mendukung hal tersebut dalam penelitiannya yang mengemukakan bahwa kurikulum berbasis virtual and physical mobile (CVPM) sangat menghargai siswa dan guru, karena model ini tidak hanya memperkuat hubungan antara museum dan kurikulum dasar tetapi juga meningkatkan persepsi dan sikap positif siswa terhadap alam. Hal ini menunjukkan bahwa penggunaan m-learning dalam kegiatan pembelajaran mendapatkan respon yang baik dari peserta didik. Pengembangan m-learning yang didukung aspek suara, video, animasi, teks, dan grafik mampu mempermudah peserta didik dalam belajar (Fikri \& Madona, 2018). Materi pembelajaran akan memiliki makna dan metode pembelajaran dapat terlaksana tidak hanya melalui penuturan yang disampaikan oleh guru namun juga dapat dilihat dari aktivitas yang dilakukan oleh peserta didik seperti mengamati materi yang diberikan. Penelitian (Ardiansyah, 2020) juga menyatakan bahwa pembelajaran menggunakan media pembelajaran berupa aplikasi berbasis android dapat mengaktifkan partisipasi peserta didik di kelas bahkan dapat mengaksesnya di rumah atau dimanapun. Dengan demikian, perlunya kesiapan pendidik dan juga peserta didik dalam menerima era perkembangan teknologi abad ini.
Keefektifan sebuah pembelajaran dapat dilihat dari perubahan tingkah laku peserta didik. Hasil analisis kemandirian peserta didik bertujuan untuk mengetahui keefektifan dan efisiensi sistem pembelajaran, baik yang menyangkut tujuan, materi, metode, media, sumber belajar, lingkungan maupun sistem penilaian itu sendiri (Alfiriani, 2016). Hasil analisis kemandirian peserta didik meliputi aktivitas peserta didik yang menunjukkan sikap mandiri, peserta didik memperhatikan penjelasan, bertanya jika mengalami kesulitan, selalu belajar walaupun tidak menghadapi ujian, jika mendapatkan nilai kurang akan berusaha untuk memperbaiki, menunjukkan rasa tertarik pada m-learning, merasa tertantang untuk menyelesaikan evaluasi yang ada di dalamnya dan berhasil mendapatkan hasil belajar yang lebih baik dari pembelajaran sebelumnya. Hasil analisis kemandirian peserta didik menunjukkan t-statistik $=11,689>$ t-tabel $=2,042$, maka terdapat perbedaan signifikan antara $X_{1}$ dan $X_{2}$. Hal ini juga didukung oleh penelitian (Havizul, 2019) yang menyatakan bahwa penerapan multimedia interaktif dalam kegiatan pembelajaran IPS dipadukan dengan model pembelajaran kontekstual untuk menciptakan proses pembelajaran yang efektif, efisien, berorientasi pada konsep student centered, keterlibatan siswa secara aktif, dan memberikan pengalaman belajar langsung kepada siswa dan hasil analisis uji $t$ sampel berpasangan dan perhitungan effect size menunjukkan bahwa terdapat pengaruh yang besar dari penggunaan multimedia interaktif dalam pembelajaran IPS di SDN 06 Pontianak Kota terhadap hasil belajar siswa. (Klimova, 2019) juga menyatakan bahwa pembelajaran bahasa asing yang didukung oleh aplikasi smartphone yang dipersonalisasi dapat efektif dalam peningkatan kinerja siswa dengan menerapkan pembelajaran aplikasi smartphone dalam penilaian berkelanjutan.

Keefektifan m-learning dilihat dari hasil evaluasi yang telah diberikan kepada peserta didik yaitu pretest, LKPD dalam bentuk evaluasi yang terdapat pada $m$-learning, dan posttest. $M$ learning dianggap efektif jika pembelajaran yang dilaksanakan tuntas. Ketuntasan pembelajaran peserta didik secara individu disesuaikan dengan KKM yang ada di SDN Pucang 1 yaitu 78. 
Berdasarkan hasil pretest dan posttest yang telah dilakukan sebelum dan sesudah kegiatan pembelajaran menunjukkan t-statistik $=11,689>$ $\mathrm{t}$-tabel $=2,042$, maka terdapat perbedaan signifikan antara $X_{1}$ dan $X_{2}$. Selanjutnya, berdasarkan hasil evaluasi siswa yang telah dilakukan selama kegiatan pembelajaran berlangsung diketahui bahwa hasil belajar individu siswa ketika mengerjakan LKPD yang ada dalam m-learning, nilai rata-rata mengerjakan evaluasi tersebut 82 yang dikerjakan siswa dengan kriteria tuntas Ketuntasan individu berdasarkan KKM IPS kelas IV SD Negeri Pucang 1 yaitu 78. Hal ini juga didukung oleh penelitian (Havizul, 2019) yang mengemukakan bahwa penggunaan multimedia interaktif dalam pembelajaran IPS di SDN 06 Pontianak Kota memiliki pengaruh yang besar terhadap hasil belajar siswa. (Muttaqin, 2020) juga menyatakan bahwa multimedia lectora inspire efektif dalam meningkatkan kemampuan berpikir kritis siswa dengan hasil penerapan dari segi tes yang mendapatkan kemajuan sampai $85 \%$ dan ketuntasan belajar klasikal sebanyak $88.89 \%$ yang berarti signifikan terhadap kemampuan berpikir kritis.

\section{KESIMPULAN}

Hasil penelitian dan diskusi kesimpulan mengenai pengembangan m-learning berbasis saintifik dalam meningkatkan kemandirian dan hasil belajar peserta didik ditinjau layak dan dapat digunakan. Kevalidan m-learning dengan pendekatan saintifik berdasarkan tampilannya memperoleh nilai rata-rata 3,9 dan jika interpretsikan dalam bentuk prosentase makan akan menunjukkan angka $98 \%$ yang termasuk dalam kategori dapat digunakan tanpa revisi, sedangkan berdasarkan materinya memperoleh nilai rata-rata 3,37 dengan persentase $87,27 \%$ sehingga termasuk dalam kategori dapat digunakan tanpa revisi. Kepraktisan m-learning dengan pendekatan saintifik meliputi keterlaksanaan RPP memperoleh nilai rata-rata 4 yang kemudian diinterpetasi menjadi $100 \%$ dengan kriteria terlaksana dengan baik, dan hasil respon siswa dalam penggunaan m-learning menunjukkan kriteria respon positif yang membuktikan bahwa penggunaan m-learning dalam kegiatan pembelajaran mendapatkan respon yang baik dari peserta didik. Keefektifan m-learning dengan pendekatan saintifik menunjukkan bahwa hasil analisis kemandirian peserta didik yaitu t-statistik $=11,689>\mathrm{t}$-tabel $=$ 2,042, maka terdapat perbedaan signifikan antara $X_{1}$ dan $X_{2}$, sedangkan hasil hasil pretest dan posttest menunjukkan t-statistik $=11,689>\mathrm{t}$ tabel $=2,042$, maka hasil belajar siswa mengalami peningkatan yang cukup signifikan dalam pembelajaran menggunakan m-learning.

\section{DAFTAR PUSTAKA}

Alfiriani, Adlia. (2016). Buku Ajar Evaluasi Pembelajaran dan Implementasinya. Padang: Sukabina Press.

Ardiansyah, Abd \& Nana, Nana. (2020). Peran Mobile Learning sebagai Inovasi dalam Meningkatkan Hasil Belajar Siswa pada Pembelajaran di Sekolah. Indonesian Journal Of Educational Research and Review. 3. 47. 10.23887/ijerr.v3i1.24245.

Asrori, M. (2015). Perkembangan Peserta Didik: Pengembangan Kompetensi Pedagogis Guru. Yogyakarta: Media Akademi.

Daryanto. (2010). Media Pembelajaran. Yogya: Gava Media.

Effendi, E Zhuang H. (2005). E-learning Konsep dan Aplikasi. Yogyakarta: Andi offset.

Fikri, H., \& Madona, S. A. (2018). Pengembangan Media Pembelajaran Berbasis Multimedia Interaktif Pada Mata Pelajaran Biologi. In Penerbit Samudra Biru (Anggota IKAPI) (Vol. 5). https://doi.org/10.24114/jtikp.v5i1.12524.

Havizul. (2019). Pengembangan Multimedia Interaktif untuk Pembelajaran IPS di Sekolah Dasar Menggunakan Model DDD-E. Sosial Horizon: Jurnal Pendidikan Sosial, Vol.6, No.2, 283-297. http://dx.doi.org/10.31571/sosial.v6i2.1202.

Ivers, Karen. S. \& Ann E. Barron. (2002). Multimedia project in education: designing, 
producing, and assesing. United States of America: Libraries Unlimited.

Klimova, Blanka. (2019). Impact of Mobile Learning on Students' Achievement Results. Education Sciences. 9.90. 10.3390/educsci9020090.

Melvin L. Silberman. (2006). Active learning 101 Cara Belajar Siswa Aktif. Bandung: Nuansa.

Muttaqin, M., Siswono, T., \& Lukito, A. (2020). Pengembangan Multimedia Lectora Inspire untuk Meningkatkan Kemampuan Berpikir Kritis dalam Menyelesaikan Soal Cerita Bangun Ruang. Jurnal Cendekia : Jurnal Pendidikan Matematika, 4(2), 495-511. https://doi.org/10.31004/cendekia.v4i2.259

Qohar, A. (2011). Pengembangan Instrumen Komunikasi Matematis Untuk Siswa SMP. Lomba dan Seminar Matematika XIX. UNY: Yogyakarta.
Sugiyono. (2017). Metode Penelitian. Bandung: Alfabet.

Surjono, Herman Dwi. (2017). Multimedia Pembelajaran Interaktif. Yogyakarta: UNY Press.

Tien-Yu Hsu Fan-Ray Kuo Hsin-Yi Liang MinFeng Lee. (2016),"A curriculum-based virtual and physical mobile learning model for elementary schools in museums", The Electronic Library, Vol. 34 Iss 6 pp. 997 1012.

Utami, R.E., Nugroho, A. A., Dwijayanti, I dan Sukarno, A. (2018). Pengembangan E-Modul Berbasis Etnomatematika Untuk Meningkatkan Kemampuan Pemecahan Masalah. JNPM (Jurnal Nasional Pendidikan Matematika) Vol. 2(2), Hal.268283.

http://dx.doi.org/10.33603/Jnpm.V2i2.1458. 